Article

\title{
Popular Songs, Melodies from the Dead: Moving beyond Historicism with the Buddhist Ethics and Aesthetics of Pin Peat and Cambodian Hip Hop
}

\author{
Jeffrey Dyer \\ Department of Musicology and Ethnomusicology, Boston University, Boston, MA 02215, USA; jmdyer1@bu.edu
}

Received: 1 October 2020; Accepted: 9 November 2020; Published: 22 November 2020

\begin{abstract}
This article illustrates how the aesthetics of two types of Cambodian music-pin peat and Cambodian hip hop-enact Cambodian-Buddhist ethics and function as ritual practices through musicians' recollections of deceased teachers' musical legacies. Noting how prevalent historicist and secular epistemologies isolate Cambodian and, more broadly, Southeast Asian musical aesthetics from their ethical and ritual functions, I propose that analyses focusing on Buddhist ethics more closely translate the moral, religious, and ontological aspects inherent in playing and listening to Cambodian music. I detail how Cambodian musicians' widespread practices of quoting deceased teachers' variations, repurposing old musical styles, and reiterating the melodies and rhythms played by artistic ancestors have the potential to function as Buddhist rituals, whether those aesthetic and stylistic features surface in pin peat songs or in hip hop. Those aesthetic practices entail a modality of being historical that partially connects with but exceeds historicism's approach to Buddhism, temporality, and history by enacting relations of mutual care that bring the living and dead to be ontologically coeval. Such relational practices bring me to conclude with a brief discussion rethinking what post-genocide remembrance sounds like and feels like.
\end{abstract}

Keywords: popular music; efficacy; musical aesthetics; historicism; Buddhist ethics; ontologies of living-dead relations; post-genocide remembrance

\section{Introduction: Popular Music and Beyond-Human Listeners}

Late one night at a Buddhist monastery in rural Cambodia, a small group of people hung out by the central sanctuary, drinking beer, talking energetically, and listening to music. Musicians played nearby on a temporary stage erected within the monastery's grounds. Two singers and a small dance troupe fronted the instrumentalists, and on the dirt field below the stage at least two dozen people danced along to the songs. These festivities were part of the ritual that a group of siblings were sponsoring to mark the 100-day cycle following their mother's death and the 10-year cycle following the death of their father. That afternoon, relatives and friends had gathered as the ritual commenced. Musicians played songs inviting a series of deities; everyone chanted to recall their ancestors' legacies and to support the Buddha, Sangha, and Dharma; and monks chanted to dedicate merit to the dead. Those activities complete, it was now time for the party.

I approached the sanctuary and sat next to Keo Sonan Kavei and Keo Dorivan, two brothers who had helped organize this ritual for their dead parents. Both men and all of their siblings are musicians, and they all first studied with their father, Keo Snguon, who had specialized in the pin peat songs that accompany Cambodian court dances and invite deities and ancestors to Buddhist rituals such 
as this one. ${ }^{1}$ Those were the songs Keo Snguon taught to his children, and they were the songs Keo Sonan Kavei—or Grū Kavei as I referred to him, the word grü being Khmer for teacher ${ }^{2}$ - taught to me when I began studying with him a few months before this ritual. The songs the band played that night sounded far removed from that ritual music. They offered K-pop tunes, classic Cambodian rock and roll, and several hip hop songs. The singers sang current hits and popular old melodies while the keyboardist imitated the sounds of traditional Cambodian instruments and produced synthesized timbres common to urban dance clubs around the world. Pre-programmed drum tracks produced the saravan, kantreum, and lamliev rhythms that have driven Cambodia's popular music for decades, and the band played several Cambodian rock songs first recorded in the 1960s, refurbishing them with synthesized swells, reggae rhythms, and at times hip hop lyrics. ${ }^{3}$

This type of musical quotation and development is common across the world. Jazz and rock musicians, classical composers, and many others quote their predecessors and repurpose old aesthetic features in what might be termed a dialectic of continuity and change. Historical musicologists and ethnomusicologists have long traced those historical influences and diachronic development, and such historical excavation could fruitfully analyze the music played that night. However, Grū Kavei indicated that, for him, those songs' importance moved beyond the facts of their historical influences when he looked toward the dancers and spoke of his dead parents. He told me, "My mother and father are here. They like these songs, and they are watching all of them dance". What I did not realize until that unprompted aside is that what I heard as secular pop tunes were, to Grū Kavei's ears, ritually efficacious songs and an integral component of his Buddhist practice.

This article traces how the two frameworks embedded in the previous paragraph produce very different understandings of pin peat songs and Cambodian hip hop. The first framework is historicist; the second is what I will term Cambodian-Buddhist ethics. ${ }^{4}$ Both frameworks relate to the past, but as I will detail, they produce radically different modes of being historical. Historicism, which emerged along with its close relative secularism as part of Enlightenment rationality, is "the idea that to understand anything it has to be seen both as a unity and in its historical development" (Chakrabarty 2000, p. 6). As such, historicist thinking produces factual and secular understandings of musical progress over time by tracking musicians' development of predecessors' work. In contrast, through Buddhist ethics, Cambodian musicians recall predecessors' legacies in ritually efficacious recollections that bring the living and dead into relations of mutual care. At Grū Kavei's ritual, the efficacy of those popular songs emerged through several contextual factors: their temporal placement within the broader ritual, their location within a Buddhist monastery, and that Grū Kavei had directed the band's songs toward their beyond-human listeners by angling the stage to face the stupa holding his parents' bones. But, as I would learn, those songs' efficacy also emerged through sounded aesthetic features-quotations of predecessors' melodies and lyrics, reiterations of decades-old rhythms, and imitations of the

1 For well-known Khmer terms such as pin peat, I use the common spelling, which typically follows the phonology. On the first instance of those cases, I will provide the orthographic transliteration either in parentheses or a footnote, following the ALA-LC Khmer Romanization Table. For all other Khmer words, I use the ALA-LC's system. For people's names, I follow each individual's preferred spelling. Pin peat's orthographic equivalent is bin bādy.

2 In addition to "teacher," the word gru refers to traditional Cambodian doctors, some guardian beings, and even several deities. Many musicians used the term to refer to deities who oversee the music, whom some consider to be their personal teachers. Many also used gru to refer to all the deceased musicians who came before. At times, referring to one's living music teacher as a $g r \bar{u}$ carries those spiritual connotations.

3 I distinguish between Khmer - a language and an ethnic category-and Cambodian-a national category in which Khmer is the ethnic majority. The three rhythms are transliterated sār" $\bar{a} v " a ̂ n$, kandrym, and lāmlāâv.

4 I use "Cambodian" rather than "Theravadan" to refer to Cambodia's main religion. Theravada is a useful category highlighting religious continuities across Sri Lanka, Myanmar, Thailand, Laos, and Cambodia. Several aspects of what I describe resonate with practices in other Theravada Buddhist countries (McDaniel 2011; Swearer 2010, p. 1; Tambiah 1970; Wong 2001). Still, cultural differences remain, and the aesthetic priorities I emphasize may not be prevalent or even present in other primarily Theravada Buddhist countries. 
sounds of traditional instruments—and how the band repurposed old styles while embracing globally circulating genres. ${ }^{5}$

The primary claim I pursue in this article is that the aesthetic and stylistic features of pin peat songs and Cambodian hip hop enact ethical recollections that do the work of ritual technologies. Historically, scholarship on Southeast Asian musical aesthetics has obscured that music's ethical and ritual functions through two main analytical approaches. Either scholars have considered function to the exclusion of aesthetics, or they have analyzed aesthetics through secular epistemologies that isolate musical characteristics from ritual efficacy, as historicism also does. Highlighting the disjuncture between those normative analyses and Cambodians' practices and experiences, I explore what Dylan Robinson terms "epistemologies of doing" (Robinson 2019, p. 238). As I will illustrate, the Cambodian-Buddhist ethical and ritual priority of recalling predecessors' legacies (ramly k gun) infuses Cambodian musical aesthetics to such an extent that, when listening to that music-whether it is played on a stage, in a Buddhist monastery, or even recorded and posted online-we must listen to it as a ritual practice to understand what work it is doing.

In addition to taking music and rituals to be modes of action and doing (see also Asad 1993; Stephenson 2018; Sykes 2018), this paper specifies that a primary aspect of what Cambodian musical aesthetics and Buddhist rituals do is to enact relations between people, deities, and the dead within the cycle of death and rebirth (sangsār). This builds on Michael Houseman's pairing of ritual with relationality (Houseman 2006) by focusing on ritual actions and technologies rather than ritual events, which expands the actions and contexts considered to be rituals. It also shows how relations with deities and the dead are among the primary relations that Cambodians enact through Buddhist ritual practices. ${ }^{6}$ Listening to rituals and musical aesthetics in this way-as enacting ethical relations between the living and dead - undoes the naturalized distinction separating religion from the secular by locating in seemingly mundane activities and technologies the mechanisms that enact ethics and produce religious experiences through ritually efficacious sounds.

However, questions still remain. What did it feel like for Grū Kavei to listen to music with his dead parents? What do he and other musicians sense as they play melodies that enhance relations with the dead? I suggest that Buddhist ethics comes much closer than historicism to answering these questions, although I also find that identifying musical enactments of Buddhist ethics cannot capture everything that being with the dead entails. Marisol de la Cadena directly addresses this issue in her book Earth Beings about the lifeworlds of Quechua living in the Peruvian Andes (2015). By merging Walter Benjamin's thinking on translation with Eduardo Viveiros de Castro's notion of equivocation, de la Cadena points to a fundamental quandary of historical and ethnographic interpretation and the modern notion of history. Historical and ethnographic analysis becomes, in de la Cadena's thinking, an always incomplete translation "across different worlds" that are "partially and asymmetrically connected" (de la Cadena 2015, pp. 27, xii). Translation understood in this manner undermines historicism's claim to conceive history as facticity (see also Trouillot 1995), or a past that is verifiable, but it does not deny that historicist inclinations exist or that they can interact with nonhistoricist modes of being historical. This brings de la Cadena to take Quechuas' experiences of mountains as earth-beings to involve the partial connection of indigenous and nonindigenous worlds. By analyzing Cambodian ritual practices, I show how historicism and Buddhist ethics partially connect and how

5 Following a standard usage in music studies, I take aesthetics as particular sounded practices and musical components. Style is a socially constructed category that I will treat as roughly synonymous with genre.

6 Houseman's pairing of ritual and relationality is productive, but I diverge from him in two ways. Firstly, Houseman focuses on ritual events such as weddings, funerals, or ceremonies, which Cambodians term bidhi puny. The Cambodians I know conduct the ritual actions and technologies that constitute those ritual events at non-prescribed times and locations, and I consider actions in those contexts to also be rituals. Secondly, Houseman mentions human-nonhuman relationality, but he emphasizes rituals' efficacy for human-human relationality; Cambodian practices bring me to flip the emphasis. I take ritual in this context to be any action that enacts or enhances relations with deities and the dead. Religion indicates a broad system that includes theological tenets and texts, moral principles, monastic and bureaucratic structures, and ritual practices. By "religious," I denote actions and experiences that involve any aspect of a religion's principles, ethics, or aims. 
both frameworks can only partially translate Cambodians' relations with their ancestors. De la Cadena suggests this is not a problem that can be resolved but an equivocation inherent to history and ethnography. ${ }^{7}$

Still, I will detail important epistemological, ontological, and temporal differences between historicist and Buddhist modes of perceiving Cambodians' practices. Understanding living-dead relations in the context of a linear chronology confines the dead to the past and constricts living-dead relations to remembrance. In contrast, Cambodian-Buddhist ethics opens the possibility of discussing what people experience through practices that bring them and deceased predecessors to be ontologically coeval. Music is a prominent practice through which those possibilities play out. As I will show, exploring the musical aesthetics that bring Cambodians and their ancestors to relate through Buddhist ethics is not only instrumental for rethinking Cambodian music and Buddhism but also for rethinking how Cambodians experience time, history, and memory. As I discuss toward the conclusion, Buddhist ethics and their musical aesthetics also help rethink what modernity means to Cambodians and Cambodian musicians. In a country where many have died from the effects of war and genocide, the modality of translation one employs when approaching the ethical and religious practices through which the living and dead relate has far-reaching implications.

\section{Ethnomusicology and the Secular, French Colonialism and Historicism}

Taking musical aesthetics to be inherently productive of ritual practices is not how scholars have typically discussed Cambodian music. This is not to say that researchers have disregarded Cambodian music's ritual functions. Scholarship on Cambodian pin peat music and its Thai sibling pi-phat documents how that genre functions in rituals, primarily to make offerings to deities (Giurati 1999; Khoury 2017; Wong and Lysloff 1991). A large repertoire of traditional songs is an integral component of Cambodian wedding rituals (Dyer 2018; McKinley 2002). Cambodian araek songs propitiate spirits during possession rituals that provide medical care (Bertrand 2001, p. 42; Billeri 2019), and Cham possession rituals feature both Khmer and Cham music (Stock 2016, p. 790; Trankell 2003).

This scholarship clearly documents how various genres of Cambodian music function in rituals. Yet, by and large, even when researchers specialize in music, the published research rarely details musical components such as texture, rhythm, musical form, and tuning. Even fewer studies consider how those aesthetic features might relate to the music's function. ${ }^{8}$ Conversely, scholarship that does delve into musical characteristics predominantly does so by analytically isolating them from musical function (Giurati 2018; Sam 1988; Yun Khean et al. 2003). These analytical disjunctures in which scholarship considers ritual function to the exclusion of aesthetics or understands ritually functional music through a secular epistemology is hardly unique to research on Cambodian music.

One particularly pertinent example for the pin peat songs I will discuss is ethnomusicology's longstanding secular analysis of Southeast Asian musicians' heterophonies. Heterophony is the musical texture that results when musicians in the same ensemble vary a single melody simultaneously. A purely musical conception of heterophony dates at least to Mantle Hood's analysis of the musical skeleton (balungan) that Javanese gamelan musicians follow while improvising (Hood 1971). ${ }^{9}$ Hood later noted that elaborating or "filling in" a "fixed melody" is a common component of music from several countries in the region (Hood 1975). A similar idea arises in Sumarsam's coinage "inner melody" (Sumarsam 1975), by which he means the tune Javanese gamelan musicians follow internally while playing variations. Decades later, Marc Perlman analyzed three Javanese musicians' takes on the same

7 Following Castro, de la Cadena defines equivocation as "a type of communicative disjuncture in which, while using the same words, interlocutors are not talking about the same thing and do not know this." Translations acknowledge those inevitable differences and attempt to communicate through them (de la Cadena 2015, p. 27).

8 Exceptions include Deborah Wong's work on musical aesthetics in Thai Buddhism (Wong 2001) and my analysis of how Cambodian wedding musicians' aesthetic practice of playful variation contributes to the efficacy of wedding ceremonies (Dyer 2018).

9 What most music scholars now term heterophony is what Mantle Hood termed stratified polyphony. 
basic practice, which he glossed as realizing the "implicit" or "unplayed melody" (Perlman 2004). Describing Cambodian pin peat music, Sam-Ang Sam coined the term "collective melody" to refer to the collectively held nature of the melody that musicians elaborate (Sam 1988).

These analyses insightfully describe key components of several Southeast Asian musics, but they do so by considering those components in isolation. In other words, by assuming a secular epistemology characteristic of music theory, this work sequesters musical aesthetics from a ritual function. In doing so, ethnomusicology's collective exploration of Southeast Asian heterophonies becomes "a formation of the secular that produces the secular" (Sykes 2019, p. 211, referring to Asad 2003) by naturalizing the separation of aesthetics and function through assumptions inherent to the analysis. To be clear, I am not saying that this work is necessarily historicist, as music theory often assumes ahistorical guises. Still, historicism is not entirely absent, either. Perlman's intervention against music theory's decontextualizing tendencies relies on rationalist and historicist frameworks (Perlman 2004) ${ }^{10}$, and by limiting heterophony's relevant participants to living musicians, this body of research joins historicism in denying agency to the dead. The point I will eventually draw out is that the secularization these analyses enact-obscuring function by naturalizing the isolation of musical aesthetics-also occurs through historicism's cloistering of the dead in the past. In such frameworks, music can sound as remembrance, but it cannot bring living beings and dead beings together.

This distinction between a permissible mode of historical perception and historical practices that exceed the bounds of the possible has a long history stemming from Enlightenment rationality, chronological progress, and the resulting segregation of human history from sacred history, which Reinhart Koselleck has shown moved the primary domain of European politics from religious institutions to nation-states (Koselleck 1985). To Chakrabarty, historicist thinking went on to posit "historical time as a measure of the cultural distance ... that was assumed to exist between the West and the non-West" (Chakrabarty 2000, p. 7, quoted in de la Cadena 2015, p. 98). As such, it provided a civilizing logic for colonialism. Evidentiary modes of perceiving historical events based predominantly on written documentation coalesced into academic history and cordoned off verification as the realm of historical truth. In the process, other modes of sensing the past-including those emerging from myths, legends, beliefs, and music - became both unreal and historically prior, leading to what Johannes Fabian terms the "denial of coevalness" (Fabian 1983). Those whose practices did not subscribe to the paradigm of historicity-as-fact needed to catch up.

For French explorers, scholars, and colonial administrators, historicism conceived in this manner provided a lens by which they made sense of what they encountered in nineteenth- and twentieth-century Cambodia, and it drove the colonial modernity they attempted to enact during the French Protectorate (Edwards 2007; Hansen 2007; Peycam 2009). The French saw themselves as having discovered Cambodia's cultural origins in the great Angkorean civilization, thought Cambodians had forgotten or lacked awareness of that history, and perceived decline throughout Cambodian society, in particular in the arts and religion. They took visual art (Muan 2001), dance (Cravath 1985), and music (Mouhot 1864, p. 24) to all be nearing extinction. Buddhism's incorporation of magic, necromancy, and superstition, as well as Cambodians' engagement with nonhuman beings, represented both decadence and decay (Edwards 2004, 2007, pp. 97-98). What emerged was a national history based on the now-familiar trajectory of a drastic fall and French-aided recovery (Thompson 2016, p. 6; Edwards 2004).

French attempts to save Cambodian artistic practices and religion relied on European rationalist, scientific, and historicist ideals. Through the School of Cambodian Arts established in 1918 and the National Museum inaugurated in 1920, French administrators sought to connect Cambodian artists with a forgotten Angkorean heritage and to provide a better future based on France's secular

10 For instance, Perlman's stated objective is to trace "a cognitive process of creativity," and he writes that "by helping us understand how musicians come to think in new ways about their music, it may even fill a lacuna in the historiography of Western music theory" (Perlman 2004, p. 8). 
understanding of the fine and performing arts. ${ }^{11}$ Both moves were historicist, the former by uncovering a factual past, the latter by enacting what Chakrabarty terms the "'first in Europe, then elsewhere' structure of global time" (Chakrabarty 2000, p. 7). Efforts to reform Cambodian Buddhism followed a similar pattern. Colonial administrators founded the Buddhist Institute in 1930 to "rescue Cambodian Buddhism from 'degeneration'" (Peycam 2009, p. 163). By promoting the contemplation of Pali manuscripts and by attempting to exorcise ritual practices and beliefs deemed to be "Hindu" and thus "not Buddhist", French administrators collaborated with Cambodia's modernizing Buddhist monks to provide the nation with an authentic past while cultivating a future modeled on "European scientific and historicist approaches to religion" (Hansen 2007, p. 120). ${ }^{12}$ The overall effect was to move from an "aural tradition to a textual bias", and Buddhist modernizers' "insistence that meaning, and not the style or medium of reproduction, was everything ... ostensibly divested the scriptures of the magico-religious aura of the sacred writing" (Edwards 2004, pp. 68, 81). The result was the scriptural equivalent of the rationalization I described music theory enacting on Southeast Asian ritual musics.

These French interventions were, to return to de la Cadena's terminology (de la Cadena 2015), equivocations that translated one thing as something else, and what was most often lost in that translation were the deceased beings themselves. Through their attempts to provide Cambodians with a history, French colonialists collectively failed to recognize, and even did violence to, how precolonial and colonial-era Cambodians recalled and interacted with Angkorean and other predecessors through the incantations and arts of Buddhist practices (Chandler 1971; Cravath 1986; Muan 2001; Edwards 2007, pp. 97-98). Still, as Penny Edwards has observed, "[h]igh colonialism and the machinery of modernity ... never quite managed to disrobe indigenous religion" (Edwards 2004, p. 83). As a result, the split between premodern and modern Buddhism is not always that clear, and pre-colonial Cambodians' modes of interacting with deities and the dead persist in the contemporary practices I will describe, even as French colonialism's historicist narrative also endures. ${ }^{13}$

However, the nature of translation means that slippage between and within concepts and experiences will always occur, and this inevitability requires paying close attention to what concepts such as memory, history, and performing arts mean and do in particular contexts. Equivocations will arise, for instance, by forgetting that history can be felt, sensed, and sounded or that memories of deceased relatives may merge with the dead beings themselves. Moreover, in the case of Cambodians' practices of relating with the dead, the available language continues to translate between disparate analytics, in part because that language contains traces of colonial perceptions. The word "art" imperfectly translates what Cambodians' artistic practices are, ${ }^{14}$ just as "perform" does not capture what they do. For instance, the Khmer word that means "to perform"—samtaeng-also means "to manifest". The difference between a dancer performing a deity's legend and one who manifests the deity herself-which is key to the colonial-era equivocation that takes Cambodian dance to be the

11 George Groslier used the perception of decline to establish these institutions. He directed the school's visual arts curriculum (Muan 2001) and later brought royal dance to the school (Cravath 1985, pp. 187-88).

12 Cambodia's Buddhist modernization was far from straightforward, including the Thai-influenced Dhammayutti movement and the Mahānikāy order led by the Venerables Huot Tath and Chuon Nath. See Edwards (2007) and Hansen (2007) for details.

13 Such continuity even resulted from Cambodian modernizers' objectives. As Hansen writes, "the French wanted (for themselves and their Khmer colleagues) to be modern in their understanding of Buddhism; the Khmer wanted to be Buddhist in a modern world" (Hansen 2007, p. 131). Additionally, I have described how the opening lyrics Chuon Nath composed for Cambodia's national anthem do the work of a ritual inviting deities to protect the nation (Dyer 2017). Among other Buddhist traditions, McDaniel describes a case in Thai Buddhism in which surface modernization does not displace ritual function (McDaniel 2008). Sykes writes that "sonic efficacy, astrology, and drumming ... [remain] intimately tied to Buddhism as it is practiced in Sri Lanka" despite colonial Christian missionaries' best rationalizing efforts (Sykes 2019, p. 221).

14 On Cambodian visual art, Ingrid Muan writes, "But within the turn of the [twentieth] century society in which these forms were being produced, their meaning lay much more in their use for ceremonies of worship and everyday life than in a visual contemplation that turned them into objects with purely aesthetic and financial value" (Muan 2001, p. 9). My point is that aspects of that "society" remain active in the twenty-first century. 
"Royal Ballet" or a "performing art"— can thus arise without changing a word. ${ }^{15}$ I will return to this point later on. For now, I turn to Cambodian-Buddhist ethics with the goal of finding concepts and language that minimize translation's inevitable disjuncture.

\section{Cambodian-Buddhist Ethics}

At the risk of oversimplification, I might summarize historicism's general approach to the past as largely secular, factual and evidence-based, and featuring a chronological or stage-based temporality. In contrast, the modality of being historical embedded in Cambodian-Buddhist ethics is religious, entails ethical relations more than historical documentation, and is recursive without necessitating chronology. This Buddhist approach arises from the ethical and ritual practices of ramlyk gun, recalling a legacy or favor, which also drives much of Cambodian musical aesthetics.

The Khmer word gun can indicate others' good deeds, but it primarily means the concept of legacy and debt. ${ }^{16}$ Gun mainly refers to the legacies of parents and the debt children owe them, but it also signals the legacies of teachers, deities, the Buddha, tutelary land beings, ancestors in general, and many others (Walker 2018, p. 19). Humans' material existence and knowledge would not be possible without the gun of all those beings, therefore recalling those entities' legacies and repaying a debt of gratitude (i.e., ramlyk gun) becomes a lifelong priority. Many Cambodians focus on recalling the legacies of parents and ancestors, while most musicians also recall the gun of their teachers, with whom many maintain a filial-like relationship.

This ethical practice of recalling and repaying a legacy (ramly k gun) drives much CambodianBuddhist ritual activity, including most annual festivals (bidhi puny), during which people dedicate merit to the dead. Moreover, as Judy Ledgerwood has found, most Cambodians who sponsor a Buddhist ritual primarily aim "to dedicate merit to [their] ancestors" (Ledgerwood 2008, p. 157). Often, these dedications are offerings to monks who then chant to assist donors' ancestors along the cycle of death and rebirth (Davis 2016). However, as Jean Langford has shown, Southeast Asians in North America also provide material assistance to deceased ancestors by offering objects such as food, drinks, or cigarettes (Langford 2013). Similar offerings are ubiquitous in Cambodia at formal Buddhist ritual events, national ceremonies, and at non-prescribed times throughout people's lives. Recalling predecessors' legacies is embedded in these ritual exchanges. "Ramly k gun ge", "to recall their legacy (or favor)", is what Cambodians repeated to me again and again when I asked why they continually make offerings to their ancestors. Most musicians gave the same answer when I asked why they make offerings to their teachers. I have found that many consider ramlyk gun's specific type of remembrance to be an efficacious offering in and of itself, as words that recall legacies can simultaneously provide care. ${ }^{17}$

In these ways, I find that Buddhist ethics are immersed throughout people's everyday lives, as the ethical practice of recollection (ramly k gun) drives Cambodian Buddhists' diverse array of ritual actions. ${ }^{18}$ These ethics and the ritual practices of remembrance operate within a cosmology that includes unseen deities, tutelary land beings, and the dead, whose spirits can linger in this world to assist the living. ${ }^{19}$ Everyone does not experience such ontological being with the dead, but I found that most of those who voiced skepticism and accepted the dead's modern position as ontologically other still conduct rituals of ethical recollection. This seems to be the case for the musician Non Sok,

15 Performance's multivalence seems to persist. Cambodian dancers in Siem Reap say "their practice is still spiritual even if they are performing for tourists," and the dance serves "a dual duty as sacred ritual and as a form of secular entertainment" (Tuchman-Rosta 2014, p. 539).

16 Grégory Kourilsky notes that gun means "quality" or "virtue" on the Indian subcontinent and later came to mean "legacy" and "debt" in mainland Southeast Asian contexts (Kourilsky 2015, cited in Walker 2018, p. 19).

17 This is in contrast to Langford (2013) and Davis (2016), both of whom discount the role of remembrance.

18 This argument for Buddhism's popular and everyday ethics diverges from analyses that follow Max Weber in distinguishing between Buddhism as "a cultural institution and an ethical system" (Swearer 2010, p. 1).

19 In a prevalent Cambodian notion of self, each person has nineteen vital spirits (Choulean 2004; Davis 2016). 
who told me, "I do not believe we have the spirits of our teachers. But, it is important to recall their legacies (ramlikk gun), and for those of us who are alive to think of those who have died" (pers. comm., 25 October 2018). When I asked why, Non summarized the ethics of ramlyk gun, saying that his dedications to the dead remind him of the gratitude he will always owe to them.

The interrelated ethical, ritual, and potentially cosmological and ontological components comprise what I refer to as Cambodian-Buddhist ethics. In the next section, I will show how those ethics emerge through pin peat musicians' aesthetic predilection of reiterating the melodies they learned from deceased teachers.

\subsection{Playing Melodies from the Dead: Pin Peat's Buddhist Ethics and Aesthetics}

Brah Angg Tangkoe is a powerful tutelary being (anak $t \bar{a})$ whose shelter is located along Phnom Penh's riverfront walkway. ${ }^{20}$ The building's back wall faces Cambodia's Royal Palace, and its front doorway overlooks the confluence of the Mekong and Tonle Sap rivers. Urban-dwelling Cambodians can be seen visiting the shelter on any day, offering incense and bearing gifts of lotus flowers, coconut water, fruit, or more extravagant offerings. Typically, both the crowds and the gifts are largest on thngai sill, the holy day that occurs on the eighth and fifteenth days of each waxing and waning moon, when Grū Kavei and his music ensemble play pin peat songs in front of the shelter. The large drum can be heard from farthest away, and as one nears the shelter, the ensemble's texture fills in with the melodic and rhythmic interactions of various metallophones and wooden xylophones.

Brah Angg Ṭangkoe's shelter is the site of a ritual gift exchange, and "musical gifts" (Sykes 2018) are a central component of the transaction. One song costs 5000 riel, $^{21}$ and depending on how much people pay, musicians will offer sets of one, three, five, seven, or more songs on their behalf. While the musicians play, devotees typically speak to Brah Angg Tangkoe in quiet whispers to offer gratitude for assistance the tutelary being has already provided, including good luck in school, romance, or business; alleviating an illness; or providing safety for a trip. Less often, the offerings function as preemptive gifts aiming to enlist the deity's future assistance. On busy days, the ensemble plays almost continuously for a steady stream of visitors, from well before dawn until near midnight, with sets of musicians rotating through to give each other a rest.

Grū Kavei inherited this ensemble's leadership from his father, who had led the ensemble since the Khmer Rouge's fall. Keo Snguon returned to Phnom Penh in early May 1979, only four months after Vietnamese forces had expelled the Khmer Rouge from the capital. The new government, the People's Republic of Kampuchea, quickly reestablished governmental ministries, and they asked Keo Snguon to restart a music program. The previous leader of Brah Angg Ṭangkoe's ensemble was Niek Grū Makara, but she had died during the Khmer Rouge years. When the ensemble restarted in 1980, musicians chose Keo Snguon as the new leader because he had studied and played music with her (pers. comm., Keo Sonan Kavei, 2 and 8 May 2019). Grū Kavei said he started playing in the ensemble in 1996 or 1997, and he began assuming its leadership in 2000, after his father's health started to decline. To continue his father's legacy, Grū Kavei makes his ensemble's instruments following the process he learned from his father, and he tunes them to the exact pitches that Keo Snguon preferred.

In addition to the instruments and tuning, Grū Kavei recalls his predecessors' legacies (raṃlỳk gun) by playing specific variations he learned from his teachers, three of whom I will discuss here. Grū Kavei's first and most important teacher was, unsurprisingly, his father. Another teacher, Ya Long, was several decades older than Keo Snguon (see Figure 1). Ya Long played in the Royal Palace in the

20 This shelter resembles a shrine house, but I avoid that term because of its potential association with relics. The objects inside are not relics but statues of the deity, which some take to manifest the deity himself. Most villages in Cambodia have a shelter for the local tutelary being(s). Another shelter where musicians play music regularly is that of Brah Angg Cek and Brah Angg Cam in Siem Reap's provincial capital.

21 Riel (rial) is Cambodia's currency, and it exchanges at roughly 4100 riel for \$1 USD. In street transactions, sellers often exempt the 100 riel when receiving dollars, making 5000 riel equivalent to $\$ 1.25$. 
decades following Cambodia's 1953 independence from France, and he became well known for the beautiful melodies he played on the gang váng (gong circle). After Grū Kavei had learned enough melodies and variations from his father in the 1980s, he studied with Ya Long to learn that musician's gang váng variants.

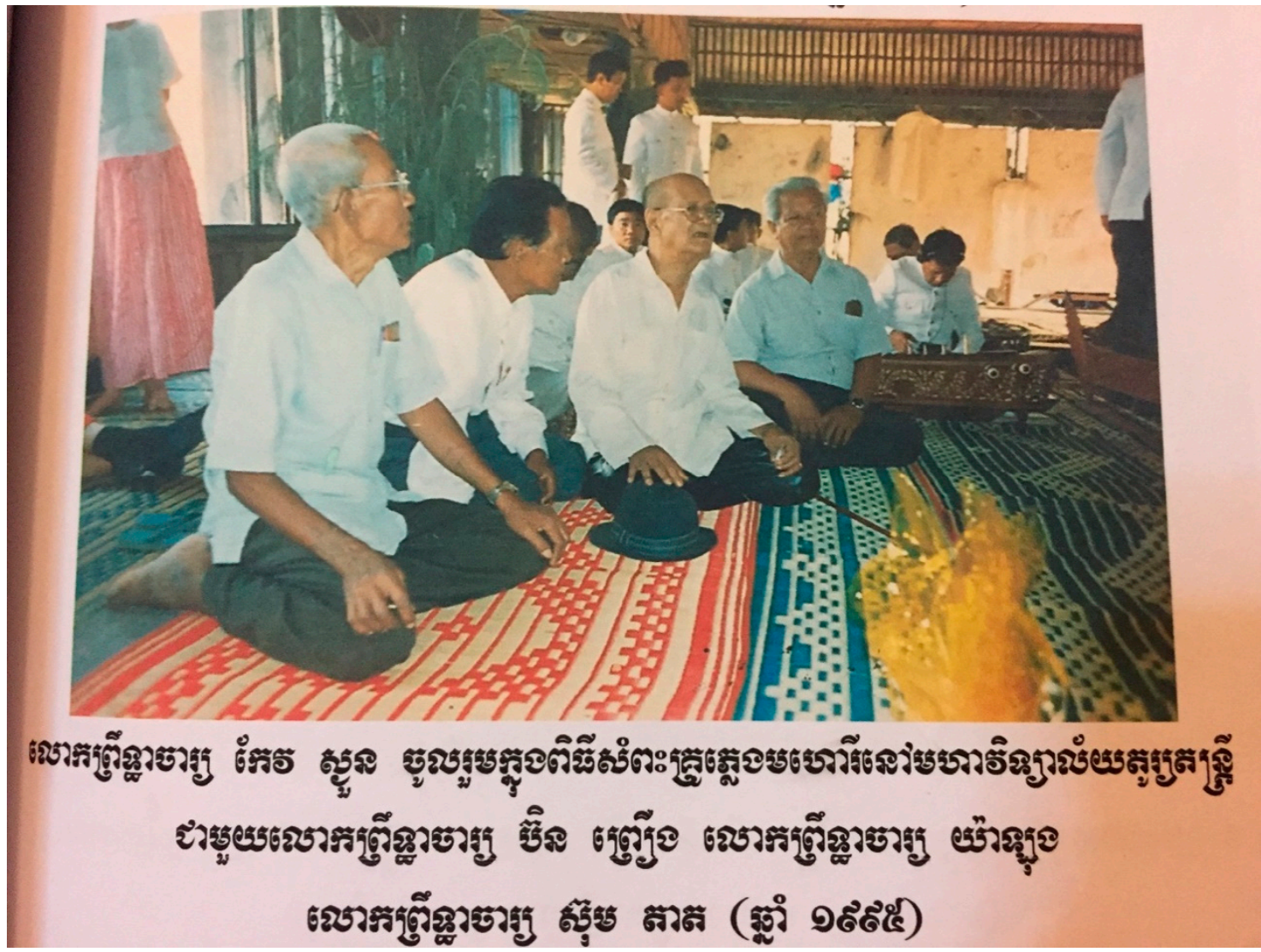

Figure 1. Keo Snguon and Ya Long: Among the musicians seated in the foreground, Keo Snguon is second from the left, leaning forward toward the man to his left, Ya Long. They are pictured at the large sambah grū ritual for mahaori (mahorī) music conducted in 1995 at the Royal University of Fine Arts. The photograph was included in an unpublished manuscript Keo Dorivan produced about his father Keo Snguon's life, which Keo Dorivan provided to the author.

Grū Kavei said his oldest teacher, Lok Ta Van, was a man he never met. Lok Ta Van played ranāt aek (lead xylophone) in the Royal Palace during the French Protectorate, and it was possibly in the 1930s or 1940s that a colonial official recorded Lok Ta Van and his ensemble. In later decades, that recording became one of many that circulated at Cambodian rituals, as sound systems operators collected recordings of pin peat music they could project through rituals' loudspeakers. Grū Kavei said those operators were oblivious to the caliber of the music they projected but that any musician could instantly recognize the remarkable qualities of Lok Ta Van's playing. His fast-paced scalar passages, trills, and intricate variations were so technically demanding that, Grū Kavei said, he has never heard another ranāt aek musician equal them. In the 1980s, Grū Kavei begged a copy from a sound systems operator and listened to it on repeat until he could play about seventy percent of what the dead musician had achieved. In this case, sound and recording technologies, which are often described as alienating and decontextualizing, effecting schizophonia (Schafer 1969) or the isolation of "listening subjects into individual 'bubbles"' (Steingo 2019, p. 41), enabled Grū Kavei to establish relations with a musician who died decades before he was born, within an ethical and religious system 
of establishing kinship with artistic predecessors. ${ }^{22}$ Such deepening of Grū Kavei's relations across time is almost the opposite of schizophonia, especially considering the ontological copresences that can arise when musicians play predecessors' variants, which I discuss in the following section.

The heterophony that Grū Kavei and his ensemble play for Brah Angg Tangkoe includes melodic variations he learned from these three deceased teachers. Figure 2, a transcription of an excerpt from the song "Sādhukār", provides one example. The top staff visualizes a variation Grū Kavei learned from his father, Keo Snguon, and the bottom staff notates the same section of the melody as it was played by Ya Long. I have marked where the two versions diverge either melodically or rhythmically.

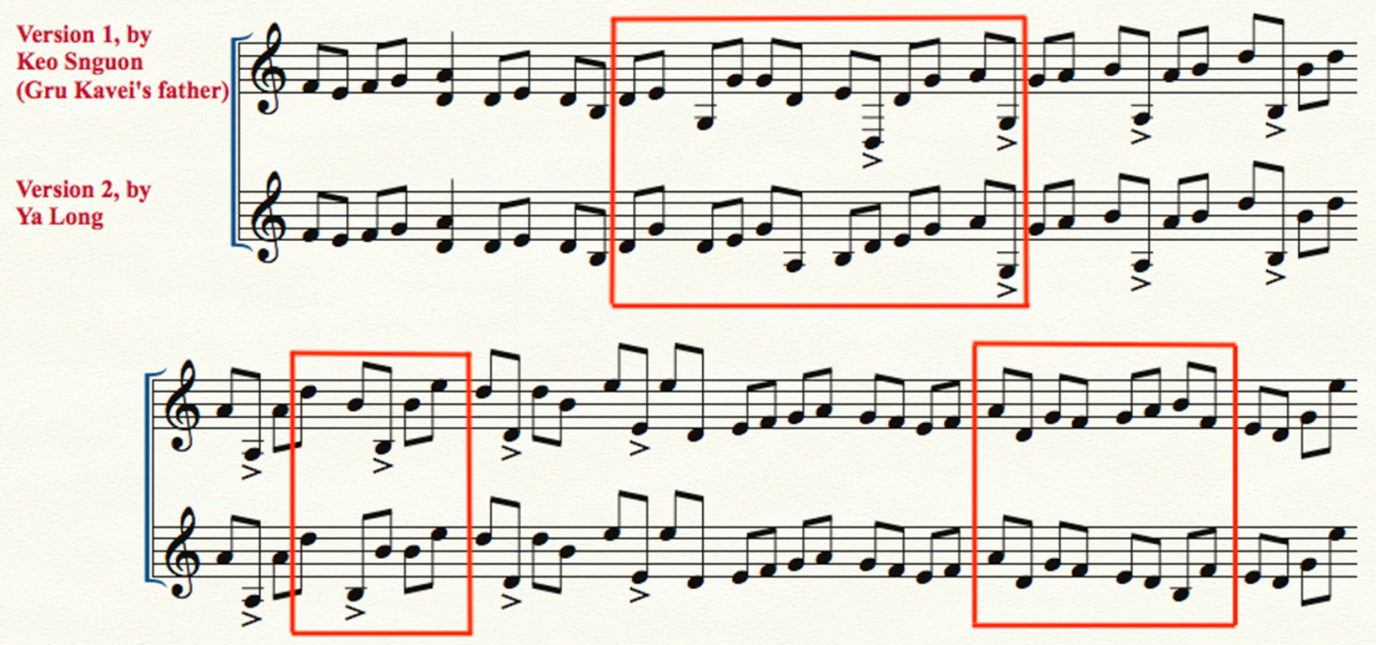

Figure 2. "Sādhukār" Variations: Two versions of a section of the song "Sādhukār", with one of Keo Snguon's versions notated on the top staff and one of Ya Long's notated on the bottom, as they were taught to the author by Keo Sonan Kavei. The boxes highlight where the variations diverge.

In practice, two musicians in the ensemble play these variants simultaneously, bringing the music of these two dead musicians to interact in a melodic conversation. At the same time, Grū Kavei might play a virtuosic embellishment he learned from Lok Ta Van or a variation he composed himself. The result, even when Grū Kavei plays solo, merges melodic snippets first played in four different historical eras. Other musicians employ similar practices. Meas Sa Em showed me his notation of the same song, "Sādhukār", which he created by fusing together variations he learned from five or six separate teachers into one composite melody (Figure 3). In that case, another modern technology - musical notation - enabled a musician to deepen relations with deceased teachers.

My analysis here does not contradict the textural analyses of Hood, Sumarsam, Perlman, and Sam I discussed earlier. There is still a fixed/inner/unplayed/collective melody that provides the basis for creative embellishment and variation. Moreover, I could add a historicist explanation for these musical practices by saying that Grū Kavei plays those variations simply because he studied with those particular teachers. That statement is not incorrect; it simply joins the academic disciplines of history, historical musicology, and even historical ethnomusicology (McCollum and Hebert 2014) in prioritizing historical truth. ${ }^{23}$ Grū Kavei's brother, the wind musician Keo Dorivan, who sporadically

22 Steingo refers to a common trope in sound studies, particularly work on mobile listening devices. His point is similar to mine, that the widespread assumption that sound technology universally alienates and isolates is geographically particular. Steingo notes how sound technologies connect people across perceived spatial barriers; in this example, they build relations by compressing chronological time. Cambodian musicians also use technology to develop intimate relations with dead musicians by studying from recordings on YouTube.

23 McCollum writes, "History, after all is what actually happened" (McCollum and Hebert 2014, p. 231), and McCollum and Hebert take historiography to involve "rigorous examination and critique of extant sources on a topic" (p. 362). 
joins the ensemble at Brah Angg Tangkoe's shelter, offered an alternative analysis. He said, "We have the feeling that whenever we play whatever song that our teachers originally taught, the teachers who have died, we recall them already. We recall them through that variation they played. Second, by doing that, we recall their legacy" (pers. comm., 9 August 2019). What Keo described is the Buddhist ethics of recalling a legacy and repaying a debt (ramlÿk gun) enacted by playing music.

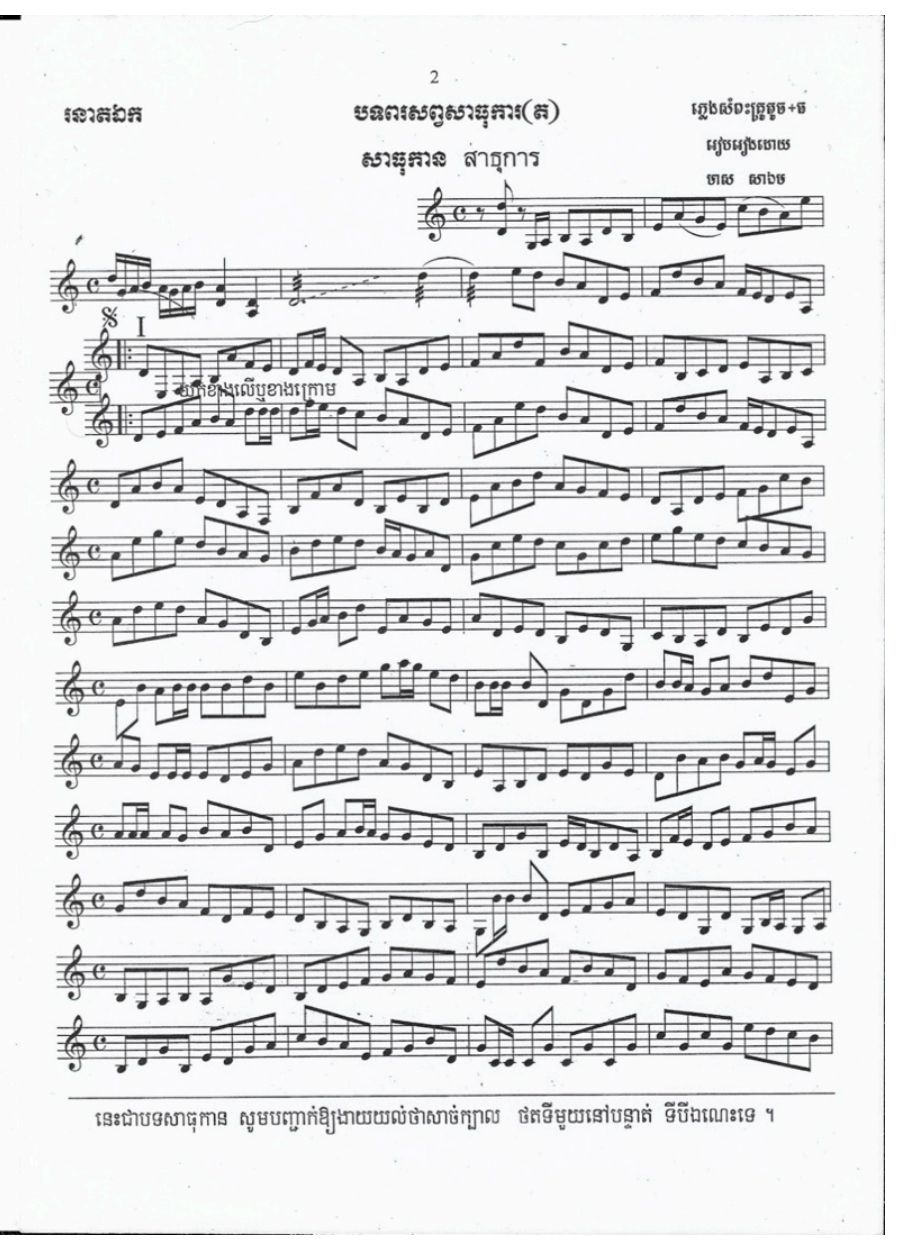

Figure 3. "Sādhukār" by Meas Sa Em: The first page of Meas Sa Em's notated version of the song "Sādhukār", for which he combined variations he learned from several different teachers.

This ethical practice of recollection through musical quotation can lead to competition between teachers. A graduate of the Royal University of Fine Arts, where Grū Kavei and Keo Dorivan teach, told me that, as a student, he played specific variations to please whichever teacher he knew was listening. He said difficulties arose when rival teachers were listening. Still, heterophony provides a technique for defusing potential tensions, as students can play multiple teachers' versions in one rendition. However, relations can strain between teachers competing among the same students for the honor of having musical descendants who will recall their legacy. This does not undermine musical aesthetics' role as a ritual technology but indicates some of the personal stakes involved when playing music functions as an ethical recollection. Some teachers and their variants may be forgotten, while others will be recalled for generations through the melodies their students play.

This practice suggests there are two forms of ritual efficacy and two sets of "musical gifts" (Sykes 2018) enacted when Grū Kavei and his ensemble play a single pin peat song. The first is for Brah Angg Tangkoe on behalf of a devotee; the second involves the musical quotations that recall deceased teachers' legacies (ramlyk gun). These are, in effect, two separate rituals that occur through the same song. In fact, innumerable rituals can co-occur through music. When his ensemble needs new musicians, Grū Kavei 
often chooses his most accomplished students, and by the time they join his ensemble, those musicians have learned the melodic variations once played by Grū Kavei's teachers. When they play those variations for Brah Angg Ṭangkoe, they will also recall and pay respect to Grū Kavei and his teachers, who have now become their teachers through Grū Kavei's tutelage. The ritualized recollections go deeper. A variation that Grū Kavei refers to as Ya Long's is the same variation that Grū Kavei's students may refer to as Grū Kavei's, because he taught it to them, just as Ya Long may have referred to the same variant as originating from his own teacher, as his teacher may also have done. In this way, Cambodian musicians recall the legacies of countless generations of musicians by playing a single variation, even if they have forgotten or never knew all of those teachers' names. Recollections build upon recollections, layering one remembrance onto another to create a music history that is both ritually efficacious and immanent to the melody.

This multilayered temporality gains yet another dimension by recognizing that Grū Kavei's students also studied with other teachers. His students can musically recall those other teachers' legacies, plus those of their teachers' teachers, in the same song with which they offer gratitude to Gru Kavei and his teachers. The result is not one recollection of one lineage but a complex web of countless ritual recollections, assembling and rendering audible a multitude of histories. Analyzed in this way, heterophony is much more than a musical texture in which a theme and its variations co-occur; rather, that texture is a technology for enacting Buddhist ethics by repaying debts to countless generations and lineages of ancestors, all recalled through the melodic variants of a single song.

\subsection{Copresence and Memory}

The practices I described above diverge from historicism in at least three ways. Firstly, they produce a music history that is primarily aural with some written elements. They also involve a temporality that is simultaneously linear (musicians recalling a lineage of teachers), cyclical or reiterative (the same basic melody repeating over days, months, and decades), and multilayered (accommodating co-occurring recollections of multiple lineages). Thirdly, the aesthetic reiteration of teachers' variants does the ritual work of enhancing relations with dead teachers while enacting the priorities of Buddhist ethics. This section explores a fourth divergence from historicism: how musicians' perceptions of deceased teachers as supportive copresences bring the living and dead to be ontologically coeval.

The backdrop for this observation is the prevalent assumption that Western modernity has relegated the dead to the past. For Joseph Roach, Enlightenment rationality silenced "the gregarious presence of the dead" to the extent that modernity itself is marked by the "segregation of the dead from the living" (Roach 1996, pp. 50, 48). Even Jason Stanyek and Benjamin Piekut's conception of "deadness", which elucidates many fissures by which the living and dead relate through sound recording technologies, accepts the basic premise of the mundane modern world's naturalized separation of living from dead (Stanyek and Piekut 2010). This separation informs the academic production of historical knowledge. As Stephan Palmié has shown regarding Afro-Cuban rituals, academic history's privileging of verifiable facts excludes other modalities of being historical, including drumming through which the living and dead relate (Palmié 2014). This schism extends to modern conceptions of memory, including Pierre Nora's definition of the lieux de mémoire as "shells on the shore when the sea of living memory has receded" (Nora 1989, p. 12). These conceptions of the past "as past" emerge from within historicism's chronological temporality that imagines "what was" to be a continually fading frontier.

Although, if the living and dead have parted ways, then what can I make of my music teacher listening to rock music and hip hop in the company of his deceased parents? How might I analyze Grū Kavei's heterophony when his dead father and a musician who died decades before Grū Kavei's birth are among his musical interlocutors? Grū Kavei's brother Keo Dorivan already outlined one answer: analyzing the reiteration of dead musicians' melodies as ethical recollections. But, when I joined Keo Dorivan at his house in Phnom Penh and asked about his experience of playing the song "Khmer Loeng Brah Banlā", he indicated that playing the melodies of the dead generates something else as 
well. I had learned "Khmer Loeng Brah Banlā" from Grū Kavei, and he told me that it is a special song for him and his family, being the first song that he and his siblings learned from their father, Keo Snguon, and the first song Keo Snguon learned from his own father, Keo Sa. I asked Keo Dorivan what he feels when he plays that song as an adult. Miming the motions of playing the instruments he named, Keo replied that playing that song brings him to recall when, "my father, he held the hands of the ranāt (xylophone) player to have him play like this, the khluy (flute) player to play like this, I remember that. When we play that song, we recall him and he comes here".

There are several layers of experience, memory, and copresence to unpack from his response. In Paul Connerton's terminology (Connerton 1989, p. 20), Keo Dorivan's embodied "habit-memory" through which he remembers the gestures that produce the melody blurs with the "cognitive memory" of his first moments studying music, suggesting that cognition is intimately linked with kinesthetic movement. Still, both types of memories, if they can be separated, seem to co-occur with his father's arrival. This immediacy of sensing a past moment and his father's copresence suggests that the term "memory" falls far short of translating what Keo Dorivan experiences through this song. So, too, may the construct of ritual as a "performance", which remains a popular framework in studies of Buddhist rituals (Cupchik 2015). For Richard Schechner, whose conversations with Victor Turner helped initiate a performance studies approach to rituals, "Performance means: never for the first time. It means: for the second to the $n$th time" (Schechner 1985, p. 36). By omitting the "first time", this analytic of performance-as-ritual becomes an equivocation set at least one step removed from Keo Dorivan's experience of "we recall him and he comes here". If the Khmer word samtaeng is appropriate for this experience, it seems to be as a manifestation (samțaeng) and not a performance (samtaeng) of Keo Dorvian's father and, perhaps, even of his early experience studying music.

Alternative translations abound. One is to suggest that Keo's experience of the Khmer word ramlìk, like its English equivalent "recall", includes the sensations of "to summon" as well as "to recollect". De la Cadena suggests something similar, writing that "earth-beings do not just have names; they are when mentioned, when they are called upon" (de la Cadena 2015, p. 25). Another possibility is that, as in Marcel Mauss's observation about hau, "the spirit of things" (Mauss 1990), musicians' legacies contain something of their selves, ${ }^{24}$ and that playing a dead musician's melody manifests something of that musician, bringing the living and dead musicians into each other's company. That is about as far as my speculations can go. I have not experienced Keo Snguon's arrival when I have played this song, so I can understand some of what Keo Dorivan means, but I lack the sensations to better translate what he experiences. What seems clear is that to gloss Keo's experience as a performance or in the historicist language of remembrance forecloses these possibilities from the start.

Perhaps sensing these limits to our attempted translation, Keo tried again to describe what playing this song does for him. He said:

So, I recall my father's variation recalling that, 'Oh, his hands played like this.' And so one could say that he is right next to me, in order to help, help me have energy, to help have energy and to remember really well. In previous eras, we didn't have notation, so we would remember, we would remember by the sensations. And so, we recall the legacies (ramliyk gun) of our teachers.

Keo Dorivan then said that his father's arrival feels like being possessed, resulting in the positive sensations of support for his arms and physical guidance as he plays. Again, there are several levels of subjectivity, memory, and temporality to unpack, as a shadowy merging of bodies and persons also blurs moments in time, troubling any clean distinction separating a living self from a deceased other and the present from the past. Keo described how present-tense action conjures the memory of a past

24 Even when a gift "has been abandoned by the giver, it still possesses something of him." Thus, "it follows that to make a gift of something to someone is to make a present of some part of oneself," and "to accept something from somebody is to accept some part of his spiritual essence, of his soul" (Mauss 1990, p. 12). 
event in a way that recalls Henri Bergson's claim that, "it is from the present that comes the appeal to which memory responds, and it is from the sensori-motor elements of present action that a memory borrows the warmth which gives it life" (Bergson 1962, p. 197). However, Keo's sensation of being possessed or inhabited by his father, who provides energy and support for his arms, both bolsters his cognitive/habit memory and exceeds what a modern conception of memory entails. For Keo Dorivan, his father may be dead, but he is ontologically present, someone whose human existence has run its course but who still intercedes in his life and arrives alongside him when he plays music.

I began to ask Keo Dorivan why this song, and not others, affects him so deeply, but he quickly interrupted me to say that particular song was just one example:

When I play khluy (flute) or I play any song, I recall my father, and I recall my other teachers, because it is their variation. According to the section of the music I'm playing, I remember those teachers who played it, and they stay beside me through that music's content. (pers. comm., 9 August 2019)

It is not just a special song that can give rise to a dead teacher. Rather, playing any melodic variant can recall the legacies of teachers and bring them to take a seat by his side.

Keo Dorivan is far from the only Cambodian musician to describe sensing a teacher or parent through song. Many described feeling chills, a tingling sensation in their arms, a weight on their back, increased energy, or an effervescence of sensation as indications of a teacher's proximity. Some were more specific. The wind musician Yim Chanthy, who first studied music with her father, the great flute musician Yim Saing, told me that, "Sometimes when I play music, I see [my father] next to me. That's when I feel especially strong" (pers. comm., 4 May 2019). The musician Men Mao said that, whenever she plays the first song she learned, she is not only thrown into her first moments studying music, but she also experiences the proximity of her mother, Long Thuon, who taught her singing and drumming but died unexpectedly several years ago. Mao's experience parallels Keo Dorivan's, but hers may be more ambiguous. She told me, "I still sense that my mother is alive. It is like a lie I tell myself to keep moving. Others say she is dead, but I have the feeling that she is still alive and with me" (pers. comm., 20 July 2019). Mao and, as she indicated, others around her are clearly aware of the idea that death effects an unbridgeable separation, but she is also aware of how her experiential sensations diverge from that prevalent assumption.

For many Cambodians, it seems that what keeps the dead alive, not just as memories but as interlocutors and companions, are the practices of Buddhist ethics. But, while the vast majority of Cambodians I know enact those ethics through prescribed actions conducted at delimited locations and times, a great diversity of actions give rise to sensations of the dead. For some musicians, deceased teachers arrive along with the ethical recollection of playing a melody. Grū Kavei felt a similar sensation while listening to Cambodian rock and hip hop. For musicians and non-musicians, deceased ancestors can also live in the quiet moments of everyday life when a whispered recollection, murmured name, or small offering weave the dead into the living's world. For instance, take how the Phnom Penh-based journalist Po Sakun described her process of traveling to unfamiliar locations:

When I go any place far away or to any place that I've never been before, or when I stay somewhere that doesn't have safety, I have the feeling that I am scared of bad people who might mistreat me, or I'm afraid of bad ghosts who could harm me. I usually do something good for my ancestors and deities so they can help protect and care for me. At that time, I have a strong moral force and I clearly know at about $90 \%$ that I will not have anything happen to me, because my ancestors are alongside me to protect and care for me. So, I'm not scared if I meet a man who I don't know. (pers. comm., 7 May 2019)

The sensation of being alongside the dead, which Keo Dorivan and others experience when playing deceased teachers' variations, is what Po Sakun feels as a "strong moral force" after she does "something good for [her] ancestors". In the next section, I further explore the diversity of sounds and actions 
through which Cambodians recall predecessors' legacies (ramliyk gun) by considering how relations with the dead arise through music that both involves and exceeds historicist inclinations.

\subsection{Partial Connections betweeen Historicism and the Buddhist Ethics and Aesthetics of Cambodian Hip Hop}

Arguing for the religious aesthetics of pin peat songs may seem to be an obvious fit because those songs already function in Buddhist ritual events. However, Grū Kavei and I were not listening to pin peat songs but to Cambodian pop, rock, and hip hop when he leaned over during his ritual to tell me that his dead parents were not only listening but that they liked what they heard. Which aspects of those musical aesthetics pleased his parents? Does quoting dead musicians' melodies and rhythms still do the work of ritual recollections when those quotations resound through globally circulating genres? How might the aesthetics of Cambodian hip hop enact Buddhist ethics?

In addressing these questions, I will not argue that all pop songs and hip hop produced in Cambodia contain the potential to be functionally Buddhist. Some popular songs do not entail recollections that do the work of Buddhist ethics. However, when attending to aesthetics and styles, deciding which songs do and which do not contain the potential for ethical recollections becomes difficult. While certain aesthetic practices such as reiterating melodies, rhythms, and lyrics are audible, the socially constructed nature of style renders its functionality open to interpretation, so that the same song can function differently for different listeners. Moreover, even when musicians clearly recall their predecessors' legacies, historicist trajectories and inclinations also seem to reverberate. This is what de la Cadena, building on Marilyn Strathern, terms "partial connections" (de la Cadena 2015). Through my consideration of pop songs and hip hop, I will show how Cambodian-Buddhist ethics and historicism can connect and intertwine while never reducing the former to the latter. I will suggest that to maintain the partiality of partial connections and show how Buddhist ethics may involve but exceed historicism's logic, it is necessary to listen for what musical styles and aesthetics do and what ethical relations they enact for those who produce and listen to this music.

Western music instruments and musical genres such as marches, fanfares, and French chansons have been in Cambodia since the French Protectorate, ${ }^{25}$ and Afro-Cuban musics arrived in Phnom Penh via Manila by the 1930s (Mamula 2008, p. 29). Those and other novel musics became increasingly popular during Cambodia's modernizing heyday following its independence from France (Daravuth and Muan 2002). From the mid-1950s through the mid-1970s, Cambodian songwriters such as Kong Bunchhoeun, instrumentalists such as Yol Aularong and the guitar band Baksei Chamkrong, and singers including Sinn Sisamouth, Ros Serey Sothea, and Pen Ron produced a diverse array of original songs. That music featured such stylistic influences as Afro-Cuban rhythms; American surf rock; Cambodian social dance genres including saravan, kantreum, and lamliev; Cambodian wedding and mahaori (mahorì) music; and hard rock from the United States. Listeners and practitioners dubbed these songs "new" or "modern" (samăy), discursively separating them from musics now termed "old" or "ancient" (purān) in a way that roughly maps onto the common distinction separating popular from traditional genres. This music scene ended with the Khmer Rouge's 1975 victory, as many of its practitioners died or fled the country in the ensuing years.

Yet, the songs those musicians produced have persisted in various forms. Well before redistributed recordings such as the 1996 compilation Cambodian Rocks gained a niche market among North Americans (Novak 2011) and eventually inspired the band Dengue Fever, people in Cambodia and Cambodian diaspora communities were playing, recording, and listening to those songs. In the 1980s, Grū Kavei

25 Cambodian ethnomusicologist Keo Narom writes that by the late nineteenth-century a brass ensemble termed "the Manila ensemble" had begun playing at Cambodia's Royal Palace, and she surmises that the "Spanish Governor" of the Philippines may have provided Cambodia's King Norodom with Filipino musicians along with the soldiers he gave to the monarch following his 1872 visit to Manila (Keo Narom 2005, pp. 90-91). By 1943, 34 Cambodian musicians plus an ensemble leader played such instruments as a clarinet, trumpet, various saxophones, and a bugle for Cambodia's royal music fanfare (National Archives of Cambodia 1942-1943, RSC \#30145). 
played in a band that recorded hundreds of classic Cambodian rock songs for distribution in Cambodia and abroad (pers. comm., 19 January 2019). By the early 1990s, singers such as Touch Sreynich and Meng Keo Pichenda also covered many of those songs on recordings and in live performances on Cambodian television. Sok Visal, who has produced much of the Cambodian hip hop that remixes earlier songs, first began to appreciate what he calls "Cambodian Golden Age Music" when he lived with a relative in the United States from 1989 to 1992 (KlapYaHandz 2019).

Non-Cambodians' claims that Cambodia's post-independence rock and roll was "lost" (Pirozzi 2014), their perspective that "the state of Cambodian popular music is precarious" (Mamula 2008, p. 38), and their efforts to save imperiled recordings (Novak 2011, p. 623) or return a cosmopolitan form to its place of creation (Novak 2011, pp. 619-20) clearly echo French colonialists' salvationist and historicist projects to rescue art they perceived to be dying or disappearing. ${ }^{26}$ Cambodians participate in this preservationist outlook as well (Barnett 1990), but their continual reproductions and creative adaptations of popular music first produced by a previous generation of musicians exceed the bounds of the historicist drive to preserve. I will detail one example by tracing a few of the many iterations of the song known as "Saravan Sleuk Kyal" or "Sleuk Kyal Dondap Mek". ${ }^{27}$

This song's basic melody appears to originate from Isan, the area of present-day northeastern Thailand that features Lao, Thai, and Khmer cultural influences. The first recording produced in Cambodia that I am aware of was sung by the popular singer So Savoeun, likely in the 1970s. That recording set the basic melody and musical characteristics common to Isan in a new arrangement with original lyrics composed by Kong Bunchhoeun, a prolific Cambodian novelist, screenwriter, and songwriter who wrote lyrics for many of Cambodia's classic rock and roll songs. The recording opened with a shimmering passage played on an accordion, which approximated the timbre of the khene (gaen), a mouth pipe of Lao origin. So Savoeun entered, singing a slow rising melody with lyrics inviting people to come and dance. Following her invitation, the accordion led into the tā lung rhythm that drove the remainder of the song. ${ }^{28}$ All of the subsequent iterations I have heard retain this basic form: a slow evocative opening that builds into a characteristic mid-tempo rhythm.

So Savoeun fled to Thailand before the Khmer Rouge's 1975 ascension, and she eventually settled in France. In her absence, Touch Sreynich, the popular singer whose career began in 1988 at the age of nine, was among those who regularly sang this song following the genocide, performing it on television and recording at least one studio version. Touch Sreynich's renditions foregrounded drum set, guitars, and keyboard, but like the older recording they also evoked the khene's timbre and used the same slow beginning, tā lung rhythm, and lyrics.

Touch Sreynich's career ended tragically in 2003, ${ }^{29}$ but "Saravan Sleuk Kyal's" popularity has persisted among Cambodian musicians, who have covered it widely. I first heard the song in 2019 when I accompanied the musician Non Sok to the Phnom Penh home recording studio Dongkhao So, where he created a version using traditional instruments for an amateur singer who wanted to record

26 This neo-colonialist preoccupation with Cambodian arts' precarity also marks much scholarship and some activism on traditional performing arts, including Robert Turnbull's (2006) and Catherine Grant's $(2016,2017)$ work on the endangerment and challenges facing Cambodian arts. See Barnett (1990) for a vigorous critique of the enduring colonialist construct of Cambodia's national endangerment.

27 In English, these song titles are "Saravan Wearing the Wind" and "Wearing the Wind, Covered by the Sky". Both phrases are poetic ways of rendering "to be naked," the latter title giving the full expression. The two titles transliterate as "Sārāvân Sliak Khyál" and "Sliak Khyál Ṭantáp Megh". All of the versions I discuss are available online. For So Savoeun's version, see: https://www.youtube.com/watch?v=_DHUEt8QySo. For one of Touch Sreynich's versions, see: https://www.youtube. com/watch?v=TRS3XDJhZ3E. For Bross La's "Saravan Remix", see: https://www.youtube.com/watch?v=hQbRPQIqrmQ. For Sreyleak's version, see: https://www.youtube.com/watch?v=D4j6FcCUlfg.

28 The ta lung rhythm is likely of Lao origin and resembles the eponymous saravan rhythm.

29 On 21 October 2003, Touch Sreynich was shot several times while shopping with her mother in Phnom Penh. Her mother died from a single bullet wound sustained during that attack, and Touch was paralyzed below her neck. The crime remains unsolved, but it is highly likely that it was politically motivated. Touch had recently released an album with controversial political content, and her attack occurred only three days after the murder of a journalist employed by a radio station critical of Prime Minister Hun Sen. 
the song. By then, popular recording artists had already released several hip hop versions online. In the mid-2010s, the hip hop artist Bross La repurposed "Saravan Sleuk Kyal" for his "Saravan Remix". He opened his version by sampling a recording of Touch Sreynich singing the introduction and main melody before he began rapping over a beat featuring vestiges of the old tā lung rhythm. Between his hip hop rhymes, Bross La sang the main melody himself, with autotuning and a synthesizer used to vary the basic tune. The contemporary pop singer Sreyleak began her own version by singing the entire slow introductory section a capella, evoking So Savoeun's vocality through a liberal use of reverb. Sreyleak's version featured an accelerated tempo and dense rhythmic texture, but a cymbal crash on the first beat of each measure led to a hand-clap on beat three, at the same moment the hand-clap emphasis fell within the cycle of the tā lung rhythm in So Savoeun's recording. This rhythmic ostinato repeated for much of the song, along with an electronic musical backing featuring a repetitive tremulous figure that seemed to evoke the khene's timbre. Over those echoes of the old rendition, the French hip hop artists Papillon and Passi and the Cambodian hip hop artist Khmer1Chivit rapped.

Through a diverse musical output, these and other artists have sustained "Saravan Sleuk Kyal" for nearly fifty years. This is one example out of many, as numerous hip hop artists have remixed pre-genocide popular songs. Sreyleak has collaborated with several hip hop artists to cover songs by the famous singers Pen Ron, Sinn Sisamouth, and Ros Serey Sothea, and songs by lesser-known singers such as Chhun Vanna and Im Song Soeum. Beyond preserving a single genre of music produced during a single historical era, these artists also foreground the sounds of traditional instruments, which many in Cambodia take to be their ancestors' legacies. In two notable examples, Aping rapped over the chayyam (chaiy'äm) cymbal rhythm that musicians play at the Buddhist ritual of puny kathin on "Ereva Chanoy", and Pou Khlaing featured the khluy (flute) on a song whose title translates as "Help Care for the Ancestors' Culture". Such ethics of care are rarely voiced outwardly but reverberate through the aesthetics of globally circulating genres, even hip hop lyrics. On Sreyleak's cover of "Konlab Slab Pich", which featured reggae-infused guitars and a Cambodian ranāt (xylophone), the hip hop artist Vitou rapped about chasing a woman's love. By doing so through the metaphor of a flower and bumblebee, he not only recalled Pen Ron's 1960s recording of the same song but also the classic Cambodian love story Tum Teav, which was first written down in the 1800s and prominently features the flower-and-bumblebee metaphor for romantic love (Chigas 2005). ${ }^{30}$

A chronological progression is clearly discernible in this musical output, but so is a collapsing of temporality. Many of these songs set melodies, rhythms, and stylistic features first popularized in Cambodia during several different decades in creative conversation with each other and with traditional music that musicians consider to be even older. Such temporal compression condenses into a single song a music history that stretches over decades or longer, resembling Sarah Politz's point that the song "Alladanou" by Benin's Gangbé Brass Band involves "many layers of history embedded in the song, coexisting and covering one another unevenly, poured on top of one another like so many sacrifices to the departed" (Politz 2018, p. 42). However, as I listened with Grū Kavei and his dead parents to songs with the same aesthetic characteristics that I have been discussing, removing the comparative "like" from Politz's statement became more than just a possibility. As the band put the stylistic features of saravan into conversation with the sounds of reggae, electronic music, and hip hop, ${ }^{31}$ Grū Kavei said that those songs did the same thing he does when weaving together variations of pin peat melodies he learned from several generations of teachers. Moreover, he said that the band's numerous means of recalling previous musicians' legacies were part of what appealed to his father,

30 Other examples of hip hop songs that foreground traditional instruments include Kelly's 2007 song “K.E.L.L.Y," Pou Khlaing's 2008 song "Yeak," and Yungsterz's 2008 song “Luk Ko Luk Krobey," all of which appeared on the music label KlapYaHandz's sole album, first released in 2012 (KlapYaHandz 2019).

31 The saravan-hip hop mixture seems to be a burgeoning style of music. On YouTube, see Sreyleak's "Saravan Rok Ku" and Pou Khlaing's "SaRaVan HipHop" as examples that seem to cite predecessors' legacies. Bross La's "The New Saravan" seems to prioritize updating rather than honoring an old form. 
because Keo Snguon had employed similar practices when he was alive. To Grū Kavei and his father, offerings in the form of recollections are not what those songs are like; offerings to the dead are what Cambodian hip hop songs are.

The extent to which remixes and sampling, hip hop rhymes and rhythms, autotuning and reverb are among the modern technologies through which musicians can recall and keep alive ancestors' legacies becomes even clearer by taking seriously the words of Sok "Cream" Visal. Sok remixed several albums of hip hop songs in the early 2000s, and in 2005 he founded the independent music label KlapYaHandz, which produced many of the songs I discussed above. Like dozens of smaller recording studios that have emerged across Phnom Penh, KlapYaHandz distributes most of its songs and music videos on YouTube and Facebook. Sok wrote on his company's YouTube page (Figure 4),

By using old Khmer music in our mix, we are trying to get the younger generation to look back to the older generation of great Khmer musicians, without whom we wouldn't be here today.

Here, Sok Visal directly acknowledges the debt the younger generation owes to their elders before specifying exactly what constitutes the older generation's legacy:

They started the fusion and the remixing, we're just keeping the tradition alive.

In contrast to historicism's search for origins, Sok Visal takes the older generation's legacy not to be a specific genre or instrument but what he calls a tradition of remixing. Sok directly refers to the generation of musicians who produced Cambodia's pre-genocide rock and roll, but as Grū Kavei discussed, a similar repurposing of predecessors' melodies marks pin peat musicians' practice.

At his statement's conclusion, Sok describes this aesthetic of remixing in the language of the Buddhist ethics of recalling ancestors' legacies (ramlyk gun).

Our ancestors have left us concrete proofs of their great artistic skills for us to live on and to shine again. We pay respect to them and show our appreciation by keeping their legacy alive, and by putting "KHMER" back on the map of the World. (KlapYaHandz n.d.)

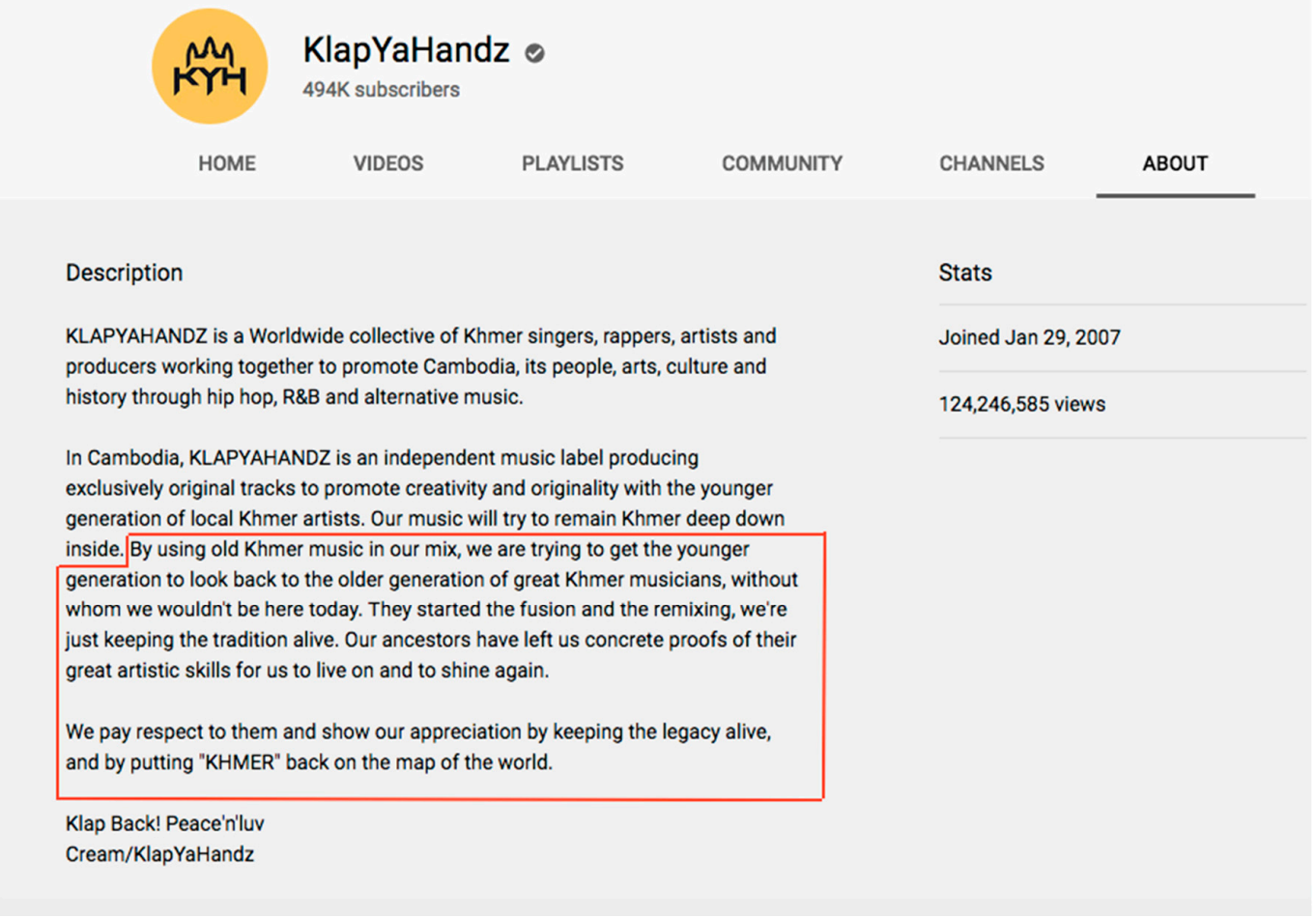

Figure 4. KlapYaHandz: A screenshot of the YouTube page where Sok "Cream" Visal analyzes the hip hop his company produces through the Cambodian-Buddhist ethics of ramlyk gun. 
At times in this article, I have presented historicism and Cambodian-Buddhist ethics in a binary opposition, but here the relationship is not oppositional. Sok Visal does not oppose the national chronology positing Cambodian loss, decline, and eventual recovery, what Chakrabarty terms "the 'not yet' of historicism" (Chakrabarty 2000, p. 8). Rather, Sok Visal and KlapYaHandz connect with and even embrace that national narrative while changing the framework within which it operates. They do not put "'KHMER' back on the map of the World" merely to recover lost greatness but transform that historicist impulse left over from French colonialism into an ethical practice that honors ancestors by recalling their legacies. Once again, an analysis that opts for historicism and one that highlights Cambodian-Buddhist ethics "partially connect" but still describe two different things.

Historicism has initiated many changes around the world, but KlapYaHandz's enactment of Cambodian-Buddhist ethics brings into question the extent to which modernity has severed a modern present from a pre-modern past. Certainly, Cambodia is full of modern objects. Recording technologies, electric guitars, hip hop lyrics, and a historicist national narrative are among the modern technologies I have discussed. What I have tried to illustrate through musicians' enactments of Cambodian-Buddhist ethics is that embracing modern technologies does not necessitate the adoption of modern epistemologies. Cambodians' ethical and ritual practices and some people's ontological being with the dead persist, even as they take novel forms. I have argued that such practices are audible in the aesthetics of pin peat songs and Cambodian hip hop, both of which do the work of Buddhist ethics by recalling ancestors' legacies.

\section{Epilogue: Completing Another Cycle}

The night wore on, but neither the band nor the dancers grew tired. The dancers on stage continued their coordinated gestures. Some of the ritual-goers copied those motions while others offered alternate moves. The band played more K-pop songs, classic Cambodian rock, and the saravan rhythmic substrate that underlies hip hop lyrics. Through those styles and their aesthetics, the band recalled the legacies of artists who died during the Khmer Rouge era, the singers who sang those tunes decades ago, and an instrumentalist who had recorded several of those songs himself. Keo Sonan Kavei sat quietly, enjoying the music along with his parents' company. Grū Kavei did not dance that night, but like his parents, he watched on as the others did. It seemed that, for him, as for them, listening to those songs and being together was enough.

By returning to this countryside monastery, Grū Kavei, Keo Dorivan, and all of their siblings completed another cycle, a different one from the two cyclical scales of death they commemorated with the ritual to mark the 100-day cycle following the death of their mother, Song On, and the 10-year cycle following the death of their father, Keo Snguon. From April 1975 until after January 1979, the siblings lived with their mother in this same countryside village, working in the fields and nearly starving while the Khmer Rouge were in power. In the chaos following the Khmer Rouge's 1975 victory, this family walked from Phnom Penh to Keo Snguon's natal village, the same village to which they now return for this and other rituals. Once there, the regime forced Keo Snguon to play music, separating him from his family so he could focus on playing their revolutionary songs, and leaving Song On to be near their children. Two children died, six lived, and both parents survived.

After the Khmer Rouge's fall, Keo Snguon returned to the capital before his wife and children, having been recalled to gather musicians to play for the new pro-Vietnamese government. Soon, his family joined, and before long, he was teaching music to his children and playing it himself. During one of our lessons, I asked Grū Kavei what he knew about the musician his father replaced as the ensemble leader at Brah Angg Ṭangkoe's shelter. He said he knew nothing about her besides her name and that she died during the Khmer Rouge time. So, I can only imagine what Keo Snguon may have felt as he played songs at that shelter again, reiterating the melodies of the dead, including those of his teacher and former leader, Niek Grū Makara.

Since the mid-1990s, much scholarly and media attention has described a "culture of silence" that observers say Cambodians appear to have constructed around their memories of the Khmer Rouge era 
(Boyden and Gibbs 1997, p. 146; see also Boyle 2009; Lam 2016; Mozinga 2009, among many others). By and large, observers articulate three concerns about this situation. Firstly, by not talking openly about their memories of the genocide, Cambodians remain traumatized. Secondly, by not adequately remembering and commemorating the violence publicly, they have failed to achieve justice for the victims. Thirdly, through a lack of speech and remembrance, they have failed to transmit knowledge about the genocide to the next generation. The solution, most commentators agree, is for Cambodians to begin speaking and writing about their wartime experiences in public and as often as they can. ${ }^{32}$

These concerns and the prescribed cure would be valid if historicist modes of remembrance, historical perception, and knowledge production, as well as liberal models of justice, having a voice, and political agency, were indeed universal. However, public testimony about the Khmer Rouge as a means of attaining justice, defined here as legal and political redress for historically documented crimes, seems to be less important to many Cambodians than offering ethical recollections that focus on the dead beyond the circumstances of their struggles and deaths, recalling legacies as a means of providing care. ${ }^{33}$ That is exactly what Keo Snguon, Grū Kavei, Keo Dorivan, Sok "Cream" Visal, and many others have long been doing by playing the melodies they learned from the dead.

These musicians are not the only ones to turn to Buddhist ethics in the aftermath of violence. Following Sri Lanka's decades-long civil war, the Buddhist ethics of karma provided a means of working toward "moral order" and "moral justice" while helping soldiers refashion their lives through virtuous deeds (Hughes 2013, pp. 155-56). Many Tibetans refuse biomedical definitions of trauma and find psychotherapeutic interventions to be harmful. Instead, they derive resilience and strength from the Buddhist framing of existence as suffering (Lewis 2019). Cambodians invited the spirits of deceased relatives to the Khmer Rouge Tribunal and offered testimony as ethical dedications (Hinton 2018, pp. 205-6; 208), transforming a legal procedure into a ritual action. Many Cambodians care for the genocidal dead with the same dedications they provide for all their ancestors (Kidron 2018). Moreover, when Grū Kavei and his siblings return with their spouses and children to the village where they endured the Khmer Rouge to offer merit and songs to their parents, they enact and transmit a form of historical knowledge that includes but exceeds memories of suffering. What those recollections achieve goes beyond legal definitions of "justice", just as their temporality, ethics, aesthetics, and modes of being historical move beyond historicism. If Cambodian-Buddhist ethics do entail historicist thinking, they engage those logics in the service of religious and moral ends. So too do many types of Cambodian music, whose sounds reverberate as Buddhist rituals.

The modality of recalling and caring for the dead this article has detailed-the Buddhist ethics and aesthetics of two types of Cambodian music-is thus one component of a broad social phenomenon. The ethical and religious practices that link the living and dead in relations of mutual care survived the genocide, and those practices now function to help all involved cope with the difficulties that remain. I conclude, then, by drawing an additional suggestion out of Grū Kavei's perception of his parents amid Cambodian hip hop's sounds. Declining to ask why Cambodians have not adequately spoken about a difficult past, I hope to have illustrated how a more productive line of inquiry explores how they have long been caring for themselves and all their deceased others through the practices and musical aesthetics of Cambodian-Buddhist ethics.

Funding: This research was funded by a Senior Fellowship from the Center for Khmer Studies and a Graduate Research Abroad Fellowship from Boston University.

32 These ideas embody the common assumption in trauma studies that narrative testimony enacts justice and healing (Felman and Laub 1992; Herman [1992] 2015), a notion Carol Kidron trenchantly critiques (Kidron 2009).

33 For instance, take Pham et al.'s finding that, out of the seventy-five Cambodian nationals who volunteered to provide testimony during the Khmer Rouge Tribunal's Case 001, "none of the Cambodian civil parties described a catharsis or healing effect" (Pham et al. 2011, p. 284). 
Acknowledgments: I am very grateful to Anna Stirr and the anonymous reviewers for their insightful comments. I deeply appreciate the very generous and tremendously helpful feedback I received from those who read early drafts: Marié Abe, Michael Birenbaum Quintero, Brian Barone, and FRED.

Conflicts of Interest: The author declares no conflict of interest.

\section{References}

Asad, Talal. 1993. Genealogies of Religion: Discipline and Reasons of Power in Christianity and Islam. Baltimore: The Johns Hopkins University Press.

Asad, Talal. 2003. Formations of the Secular: Christianity, Islam, Modernity. Stanford: Stanford University Press.

Barnett, Anthony. 1990. Cambodia Will Never Disappear. New Left Review 180: 101-26.

Bergson, Henri. 1962. Matter and Memory. Translated by Nancy Margaret Paul, and W. Scott Palmer. London: George Allen \& Unwin.

Bertrand, Didier. 2001. The Names and Identities of the 'Boramey' Spirits Possessing Cambodian Mediums. Asian Folklore Studies 60: 31-47. [CrossRef]

Billeri, Francesca. 2019. Interrelations among Genres in Khmer Traditional Music and Theatre: Phleng Kar, Phleng Arak, Lkhaon Yiikee and Lkhaon Bassac. Ph.D. dissertation, SOAS, University of London, London, UK.

Boyden, Jo, and Sara Gibbs. 1997. Children of War: Responses to Psycho-Social Distress in Cambodia. Geneva: The United Nations Research Institute for Social Development.

Boyle, Deirdre. 2009. Shattering Silence: Traumatic Memory and Reenactment in Rithy Panh's S-21: The Khmer Rouge Killing Machine. Framework: The Journal of Cinema and Media 50: 95-106. [CrossRef]

Chakrabarty, Dipesh. 2000. Provincializing Europe: Postcolonial Thought and Historical Difference. Princeton: Princeton University Press.

Chandler, David P. 1971. An Eighteenth Century inscription from Angkor Wat. Journal of the Siam Society 5: 151-59.

Chigas, George. 2005. Tum Teav: A Translation and Analysis of a Cambodian Literary Classic. Phnom Penh: Documentation Center of Cambodia.

Choulean, Ang. 2004. Brah Ling. Phnom Penh: Reyum Publishing.

Connerton, Paul. 1989. How Societies Remember. Cambridge: Cambridge University Press.

Cravath, Paul. 1985. Earth in Flower: An Historical and Descriptive Study of the Classical Dance Drama of Cambodia. Ph.D. dissertation, University of Hawai'i, Honolulu, HI, USA.

Cravath, Paul. 1986. The Ritual Origins of the Classical Dance Drama of Cambodia. Asian Theatre Journal 3 : 179-203. [CrossRef]

Cupchik, Jeffrey W. 2015. Buddhism as Performing Art: Visualizing Music in the Tibetan Sacred Ritual Music Liturgies. Yale Journal of Music E Religion 1: 31-61.

Daravuth, Ly, and Ingrid Muan. 2002. Cultures of Independence: An Introduction to Cambodian Arts and Culture in the 1950 's and 1960's. Phnom Penh: Reyum.

Davis, Erik. 2016. Deathpower: Buddhism's Ritual Imagination in Cambodia. New York: Columbia University Press. de la Cadena, Marisol. 2015. Earth Beings: Ecologies of Practice across Andean Worlds. Durham: Duke University Press.

Dyer, Jeffrey M. 2017. Nationalist Transformations: Music, Ritual, and the Work of Memory in Cambodia and Thailand. Yale Journal of Music \& Religion 3: 26-42.

Dyer, Jeffrey. 2018. Oral Pedagogy, Playful Variation, and Issues of Notation in Khmer Wedding Music. Ethnomusicology 62: 104-36. [CrossRef]

Edwards, Penny. 2004. Making a Religion of the Nation and Its Language: The French Protectorate (1863-1954) and the Dhammakāy. In History, Buddhism, and New Religious Movements in Cambodia. Edited by John Marston and Elizabeth Guthrie. Honolulu: University of Hawai'i Press, pp. 63-90.

Edwards, Penny. 2007. Cambodge: The Cultivation of a Nation, 1860-1945. Honolulu: University of Hawai'i Press.

Fabian, Johannes. 1983. Time and the Other: How Anthropology Makes Its Object. New York: Columbia University Press.

Felman, Shoshana, and Dori Laub. 1992. Testimony: Crises of Witnessing in Literature, Psychoanalysis, and History. New York: Routledge. 
Giurati, Giovanni. 1999. Bidhī Saṃbạ Grū Dhaṃ: Music as Ordering Factor of Khmer Religious Syncretism. In Shamanic Cosmos: From India to the North Pole Star. Edited by Romano Mastromattei and Antonio Rigopoulos. New Delhi: D.K. Printworld, pp. 89-106.

Giurati, Giovanni. 2018. Performing in empathy: Collective musical improvisation of Southeast Asia. In Free Improvisation: History and Perspectives. Edited by Alessandro Sbordoni and Antonio Rostagno. Lucca: Libreria Musicale Italiana, pp. 141-61.

Grant, Catherine. 2016. Socio-economic concerns of young musicians of traditional genres in Cambodia: Implications for music sustainability. Ethnomusicology Forum 25: 306-25. [CrossRef]

Grant, Catherine. 2017. Learning and teaching traditional music in Cambodia: Challenges and incentives. International Journal of Music Education 35: 5-16. [CrossRef]

Hansen, Anne Ruth. 2007. How to Behave: Buddhism and Modernity in Colonial Cambodia, 1860-1930. Honolulu: University of Hawai'i Press.

Herman, Judith. 2015. Trauma and Recovery: The Aftermath of Violence-From Domestic Abuse to Political Terror. New York: Basic Books. First published 1992.

Hinton, Alexander. 2018. The Justice Facade: Trials of Transition in Cambodia. Oxford: Oxford University Press.

Hood, Mantle. 1971. Aspects of group improvisation in the Javanese gamelon. In The Musics of Asia: Papers Read at an International Music Symposium held in Manila, April 12-16, 1966. Edited by José Maceda. Manila: National Music Council of the Philippines, pp. 16-23.

Hood, Mantle. 1975. Improvisation in stratified ensembles of Southeast Asia. Selected Reports in Ethnomusicology 2: 25-34.

Houseman, Michael. 2006. Relationality. In Theorizing Rituals: Issues, Topics, Approaches, Concepts. Edited by Jens Kreinath, Jan Snoek and Michael Strausberg. Leiden: Koninklijke Brill NV, pp. 413-28.

Hughes, Dhana. 2013. Violence, Torture, and Memory in Sri Lanka: Life after Terror. Abingdon: Routledge.

Keo Narom. 2005. Cambodian Music. Phnom Penh: Reyum.

Khoury, Stéphanie. 2017. On Periodically Potent Places: The Theatre Stage as a Temporarily Empowered Space for Ritual Performances in Cambodia. The Asia Pacific Journal of Anthropology 5: 444-61. [CrossRef]

Kidron, Carol A. 2009. Toward an Ethnography of Silence in the Lived Presence of the Past in the Everyday Life of Holocaust Trauma Survivors and Their Descendants in Israel. Current Anthropology 50: 5-27. [CrossRef] [PubMed]

Kidron, Carol A. 2018. Resurrecting Discontinued Bonds: A Comparative Study of Israeli Holocaust and Cambodian Genocide Trauma Descendant Relations with the Genocide Dead. Ethos 46: 230-53. [CrossRef]

KlapYaHandz. 2019. Vol. 1: The Cream of the Crop, 2001-2011. EM Records. Osaka: Japan.

KlapYaHandz. n.d. Available online: http://www.youtube.com/c/KlapYaHandz/about (accessed on 15 September 2020).

Koselleck, Reinhart. 1985. Futures Past: On the Semantics of Historical Time. Cambridge: MIT Press.

Kourilsky, Grégory. 2015. La place des Ascendants Familiaux dans le Bouddhisme des Lao. Ph.d. dissertation, École Pratique des Hautes Études, Paris, France.

Lam, Andrew. 2016. 'Daze of Justice' explores Cambodia's trauma of silence. National Catholic Reporter, May 21.

Langford, Jean M. 2013. Consoling Ghosts: Stories of Medicine and Mourning from Southeast Asians in Exile. Minneapolis: University of Minnesota Press.

Ledgerwood, Judy. 2008. Buddhist Practice in Rural Kandal Province, 1960 and 2003: An essay in honor of May M. Ebihara. In People of Virtue: Reconfiguring Religion, Power and Morality in Cambodia Today. Edited by Alexandra Kent and David Chandler. Copenhagen: NIAS Press, pp. 147-68.

Lewis, Sara E. 2019. Spacious Minds: Trauma and Resilience in Tibetan Buddhism. Ithaca: Cornell University Press.

Mamula, Stephen. 2008. Starting from Nowhere? Popular Music in Cambodia after the Khmer Rouge. Asian Music 39: 26-41. [CrossRef]

Mauss, Marcel. 1990. The Gift: The Form and Reason for Exchange in Archaic Societies. Translated by W. D. Halls. New York: W.W. Norton.

McCollum, Jonathan, and David G. Hebert, eds. 2014. Theory and Method in Historical Ethnomusicology. New York: Lexington Books.

McDaniel, Justin Thomas. 2008. Philosophical Embryology: Buddhist Texts and the Ritual Construction of a Fetus. In Imagining the Fetus: The Unborn in Myth, Religion, and Culture. Edited by Vanessa R. Sasson and Jane Marie Law. New York: Oxford University Press, pp. 91-105. 
McDaniel, Justin Thomas. 2011. The Lovelorn Ghost and the Magical Monk: Practicing Buddhism in Modern Thailand. New York: Columbia University Press.

McKinley, Kathy. 2002. Ritual, Performativity and Music: Cambodian Wedding Music in Phnom Penh. Ph.D. dissertation, Brown University, Providence, RI, USA.

Mouhot, M. Henri. 1864. Travels in the Central Parts of Indo-China (Siam), Cambodia, and Laos, During the Years 1858, 1859, and 1860. London: John Murray, vol. 1.

Mozinga, Joe. 2009. Giving a voice to 'silent suffering'. Los Angeles Times, April 12.

Muan, Ingrid. 2001. Citing Angkor: The 'Cambodian Arts' in the Age of Restoration 1918-2000. Ph.D. dissertation, Columbia University, New York, NY, USA.

National Archives of Cambodia. 1942-1943. Résidence Supérieure (RSC) File Number 30145. Box Number 3299. Musique royale et autres musiques du palais. Inventaire des instruments d/orchestra et le nom des musiciens-Statut de musique royale. Phnom Penh, Cambodia.

Nora, Pierre. 1989. Between Memory and History: Les Lieux de Mémoire. Representations 26: 7-25. [CrossRef]

Novak, David. 2011. The Sublime Frequencies of New Old Media. Public Culture 23: 603-34. [CrossRef]

Palmié, Stephan. 2014. Historicist Knowledge and its Conditions of Impossibility. In The Social Life of Spirits. Edited by Ruy Blanes and Diana Espíirito Santo. Chicago: The University of Chicago Press, pp. 218-39.

Perlman, Marc. 2004. Unplayed Melodies: Javanese Gamelan and the Genesis of Music Theory. Berkeley: University of California Press.

Peycam, Philippe M. R. 2009. Sketching an Institutional History of Academic Knowledge Production in Cambodia (1863-2009)_Part 1. Sojourn: Journal of Social Issues in Southeast Asia 25: 153-77.

Pham, Phuong N., Patrick Vinck, Mychelle Balthazard, Judith Strasser, and Chariya Om. 2011. Victim Participation and the Trial of Duch at the Extraordinary Chambers of the Courts of Cambodia. Journal of Human Rights Practice 3: 264-87. [CrossRef]

John Pirozzi, director. 2014. Don't Think I've Forgotten: Cambodia's Lost Rock and Roll. Argot Pictures.

Politz, Sarah. 2018. 'People of Allada, This Is Our Return': Indexicality, Multiple Temporalities, and Resonance in the Music of the Ganbgé Brass Band of Bening. Ethnomusicology 62: 28-57. [CrossRef]

Roach, Joseph. 1996. Cities of the Dead: Circum-Atlantic Performance. New York: Columbia University Press.

Robinson, Dylan. 2019. Speaking to Water, Singing to Stone: Peter Morin, Rebecca Belmore, and the Ontologies of Indigenous Modernity. In Music and Modernity among First Peoples of North America. Edited by Victoria Lindsay Levine and Dylan Robinson. Middletown: Wesleyan University Press, pp. 220-39.

Sam, Sam-Ang. 1988. The Pin Peat Ensemble: Its History, Music, and Context. Ph.D. dissertation, Wesleyan University, Middletown, CT, USA.

Schafer, R. Murray. 1969. The New Soundscape: A Handbook for the Modern Music Teacher. Ontario: BMI Canada.

Schechner, Richard. 1985. Between Theater and Anthropology. Philadelphia: University of Pennsylvania Press.

Stanyek, Jason, and Benjamin Piekut. 2010. Deadness: Technologies of the Intermundance. TDR: The Drama Review 54: 14-38. [CrossRef]

Steingo, Gavin. 2019. Another Resonance: Africa and the Study of Sound. In Remapping Sound Studies. Edited by Gavin Steingo and Jim Sykes. Durham: Duke University Press, pp. 39-60.

Stephenson, Barry. 2018. Ritual as Action, Performance, and Practice. In The Oxford Handbook of Early Christian Ritual. Edited by Risto Uro, Juliette J. Day, Rikard Roitto and Richard E. DeMaris. Oxford: Oxford University Press, pp. 38-54.

Stock, Emiko. 2016. Two Rituals, a Bit of Dualism, and Possibly Some Inseparability: 'And so that's how we say that Chams and Khmers are one and the same'. Sojourn: Journal of Social Issues in Southeast Asia 31: 786-825. [CrossRef]

Sumarsam. 1975. Inner Melody in Javanese Gamelan Music. Asian Music 7: 3-13. [CrossRef]

Swearer, Donald K. 2010. The Buddhist World of Southeast Asia, 2nd ed. Albany: State University of New York Press. Sykes, Jim. 2018. The Musical Gift: Sonic Generosity in Post-War Sri Lanka. New York: Oxford University Press.

Sykes, Jim. 2019. Sound Studies, Difference, and Global Concept History. In Remapping Sound Studies. Edited by Gavin Steingo and Jim Sykes. Durham: Duke University Press, pp. 203-27.

Tambiah, Stanley J. 1970. Buddhism and the Spirit Cults in North-East Thailand. Cambridge: Cambridge University Press.

Thompson, Ashley. 2016. Engendering the Buddhist State: Territory, Sovereignty, and Sexual Difference in the Inventions of Angkor. New York: Routledge. 
Trankell, Ing-Britt. 2003. Songs of Our Spirits: Possession and Historical Imagination among the Cham in Cambodia. Asian Ethnicity 4: 31-46. [CrossRef]

Trouillot, Michel-Rolph. 1995. Silencing the Past: Power and the Production of History. Boston: Beacon Press.

Tuchman-Rosta, Celia. 2014. From Ritual Form to Tourist Attraction: Negotiating the Transformation of Classical Cambodian Dance in a Changing World. Asian Theatre Journal 31: 524-44. [CrossRef]

Turnbull, Robert. 2006. A burned-out theater: The state of Cambodia's performing arts". In Expressions of Cambodia: The Politics of Tradition, Identity, and Change. Edited by Leakthina Chau-Pech Ollier and Tim Winter. New York: Routledge, pp. 167-80.

Walker, Trent Thomas. 2018. Unfolding Buddhsim: Communal Scripts, Localized Translations, and the Work of Dying in Cambodian Chanted Leporellos. Ph.D. dissertation, UC Berkeley, Berkeley, CA, USA.

Wong, Deborah. 2001. Sounding the Center: History and Aesthetics in Thai Buddhist Performance. Chicago: The University of Chicago Press.

Wong, Deborah, and Rene T.A. Lysloff. 1991. Threshold to the Sacred: The Overture in Thai and Javanese Ritual Performance. Ethnomusicology 35: 315-48. [CrossRef]

Yun Khean, Keo Dorivan, Y Lina, and Mao Lenna. 2003. Traditional Musical Instruments of Cambodia, 2nd ed. Phnom Penh: United Nations Educational, Scientific and Cultural Organization.

Publisher's Note: MDPI stays neutral with regard to jurisdictional claims in published maps and institutional affiliations.

(C) 2020 by the author. Licensee MDPI, Basel, Switzerland. This article is an open access article distributed under the terms and conditions of the Creative Commons Attribution (CC BY) license (http://creativecommons.org/licenses/by/4.0/). 